\title{
PARTICIPATION OF SMALLHOLDER FARMERS IN AGRO-PROCESSING INDUSTRIES: IMPLICATIONS FOR THE EXTENSION SERVICES OF GAUTENG PROVINCE
}

\author{
Mmbengwa, V. M. ${ }^{1}$, Rambau, K. ${ }^{2}$, Rakuambo, J. ${ }^{3}$, Tempia, N. ${ }^{4}$ and Qin, X. ${ }^{5}$
}

Correspondence author: V. M. Mmbengwa. E-mail: vmmmbengwa@gmail.com

\begin{abstract}
The study aimed to evaluate the levels of participation of smallholder farmers in the agroprocessing industries of Gauteng Province. The main objective was to determine the implications of participation or lack thereof for the extension services, using an exploratory mixed sequential design. Four focus group sessions were conducted to account for qualitative data collection, and the survey data was gathered from three regions of Gauteng Province (West Rand, Pretoria, and Germiston). A sample of smallholder farmers (n=78) was purposively selected across the three regions to select participants. The results revealed that factors such as institutional design, condition of participation, and collaboration were critical in influencing these farmers. However, the results also revealed that leadership did not affect either of the levels of participation of these farmers. Therefore, these results suggest that the level of participation in smallholder farming could be improved, should the influential factors be taken into consideration during the development planning of these farmers. It is recommended that strategic plans formulated by the supporting institutions consider these influential factors as the tools for the transformation of the agro-processing industries. These factors could stimulate participation by smallholder farmers in this sector.
\end{abstract}

Keywords: Agro-processing, Condition, Institutions, Participation, Smallholder

\section{INTRODUCTION}

Smallholder farmers are known for their critical role in potentially meeting household food security requirements and providing marketable surpluses (Akidi, Wamala \& Mugonola, 2018; Masamha, Thebe \& Uzokwe, 2018). According to Akidi et al (2018), these farmers are characterised as entrepreneurs who could be applauded for their consistent subsistence level of production for household livelihood and food security. Measures taken to enhance their education and knowledge, and developing networks for their participation at all levels of agroprocessing value chains, while simultaneously reducing transaction costs, could significantly influence small-scale agripreneurs to their benefit (Thindisa \& Urban, 2018). However,

\footnotetext{
${ }^{1}$ Manager and Research Assistant, North-West University (NWU), Marketing and Economic Research Centre (MERC), and National Agricultural Marketing Council (NAMC), Pretoria, South Africa, E-mail: vmmmbengwa@gmail.com or VMmbengwa@namc.co.za

${ }^{2}$ Research Assistant, National Agricultural Marketing Council (NAMC), Pretoria, South Africa.

${ }^{3}$ Project Manager, Gauteng Provincial Department of Agriculture, Johannesburg, South Africa.

${ }^{4}$ Head of Department and Senior Lecturer, Department of Economics, Tshwane University of Technology, GaRankuwa Campus, Pretoria, South Africa.

${ }^{5} \mathrm{PhD}$ student, Department of Risk Management, University of Pretoria, Pretoria, South Africa.
} 
S. Afr. J. Agric. Ext.

Vol. 47 No. 4, 2019: 106 - 119

http://dx.doi.org/10.17159/2413-3221/2019/v47n4a530
Mmbengwa, Rambau,

Rakuambo, Tempia \& Qin

(License: CC BY 4.0)

smallholder farmers have been criticised for producing lower quantities that cannot promote consistent supplies of food materials to the commercial markets, as well as for their limited potential to preserve their surplus food in the form of agro-processed products. It is also not known whether these farmers do conduct food processing of their products.

The construct of agro-processing participation is difficult to define in the context of the South African agricultural smallholder farming sub-sector because there is limited empirical evidence to show its existence. Participating in the agricultural and agro-processing value chain has the potential to enhance the competitive advantage of small-scale agricultural enterprises in South Africa (Thindisa \& Urban, 2018). Increasing market participation among smallholder farmers has the potential to lift them to better income levels through increased productivity and surplus production (Moono, 2015). It is increasingly being recognised that the proper exploitation of agro-processing entrepreneurial opportunities has the potential to enhance the competitive advantage of agribusinesses (World Bank, 2016).

It is also unclear if these farmers desire to participate in the established value chain and agroprocessing industries (Min et al, 2018). Agro-processing is conceptualised in South Africa as being part of the renewed effort to improve industrialised agriculture (Department of Agriculture, Forestry and Fisheries (DAFF), 2015). Several benefits of integrating the primary agriculture and agro-processing industries have been noted in the literature. These include local economic growth and development via backward and forward linkages through providing opportunities for earning income in food production, processing, distribution, retailing, and thus job creation that is encouraged by increased productivity from lower transaction costs (Dorosh \& Thurlow, 2013; Fan, Brzeska \& Halsema, 2013). This paper will use the definition of participation as espoused by numerous experts across the globe and sectoral divide (Pope, 2014). Various experts have broadly defined participation as comprising of activities that relate to involvement in contractual, consultative, collaborative, collegial; and farmer or communityinitiated interactions (Biggs, 1989; Lilja, Ashby \& Sperling, 2000). Therefore, the study aimed to evaluate the levels of participation of smallholder farmers in the agro-processing industries of Gauteng Province and to ascertain the implications of participation, or the lack thereof, for the smallholder farmers.

\subsection{Problem statement}

In South Africa, smallholder farmers are known to be marginalised (Mmbengwa, 2009; Mmbengwa et al, 2018) and thus have limited scope for participating in the agro-processing sub-sector and the entire agricultural sector. The undemocratic, apartheid South African government (before 1994) had forced these farmers to participate in agricultural activities only for their household food security (i.e. livelihood) at a subsistence level (Mmbengwa, 2009). Consequently, these farmers are intricately associated with the term 'subsistence farming'. Despite the potential benefits that might accrue from participation in agro-processing and value addition activities, these farmers are mainly confined to the informal sector and focus on primary agriculture, whereas participation in agro-processing and value addition activities could enhance their profits (Thindisa \& Urban, 2018). 
S. Afr. J. Agric. Ext.

Vol. 47 No. 4, 2019: 106 - 119

http://dx.doi.org/10.17159/2413-3221/2019/v47n4a530
Mmbengwa, Rambau,

Rakuambo, Tempia \& Qin

(License: CC BY 4.0)

\section{CONTEXTUALISATION OF THE STUDY}

Previous studies have advocated numerous benefits that smallholder farmers could gain when participating in the agro-processing sector (Alene et al, 2008; Mmbengwa et al, 2018; Thindisa \& Urban, 2018). Alene et al (2008) as well as Figueroa, Mahmoud and El-Enbaby (2018) outlined the benefits associated with participation in agro-processing, which vary and range from improved cashflow to market access, viable farming entities, and job creation. Thus, participation in agro-processing is catalytic to gaining access to the markets and the sustainability of smallholder farming (Thindisa \& Urban, 2018). According to Smith (1983), participation gives farmers the right to be consulted, involved, and be informed by other stakeholders. This kind of interaction has the potential to enrich the farmers' decision-making processes and to build trust and networks amongst the participating farmers.

Arnstein (1969) explained the theory of participation as a stepladder process and portrayed it at various levels and stages of participants' development. Arnstein's theory portrays a hierarchy of participation, where non-participation is the lowest level, which is defined by manipulation and therapy (healing). The participants who are in the lower level of participation have to demonstrate certain qualities to graduate to a moderate level of participation (the second stage of participation). This level is described as tokenism (Hurlbert \& Gupta, 2015). At this level of participation, information, consultation, and placation (conciliation) are highly prioritised for the participants (Arnstein, 1969).

According to the Arnstein theory, to develop to the tokenism stage, a participant has to show a grasp of the mentioned priorities. Lastly, the highest level of participation is described as citizen power, and it is constituted by the partnership, delegated authority, and citizen control. A participant at this stage of participation is regarded as a seasoned or high-quality participant (Rowe \& Frewer, 2000). Theoretically, these stages of participation are classified in the baseline theory of participation (Hurlbert \& Gupta, 2015). Given the participation of smallholders in agro-processing, none of the levels of participation have been documented nor published, making it difficult to assess the level and the impact of the participation. This knowledge gap makes it impossible to ascertain where future innovations, which seek to trigger impactful participation and which could alleviate socio-economic challenges, might take place.

\section{RESEARCH METHOD}

\subsection{Research design}

The study adopted an ontology philosophy which subscribes to multiple realities. These realities were influenced by the multiplicity of the material conditions in which smallholder farming in South Africa finds itself. Another philosophy that the study adopted was epistemological philosophic position. This philosophy was designed to be both constructivist and positivist. The constructivism philosophy in this study seeks to provide learning on how to enhance the participation of these farmers in the agro-processing sector. While the positivist seeks to provide certain ("positive") knowledge of the participation of smallholder farming in the same industries which is based on natural phenomena. Hence, an exploratory mixed sequential design was used. In this regard, four focus group sessions were conducted to account for qualitative data collection, and the survey data was gathered from three regions of Gauteng 
S. Afr. J. Agric. Ext.

Vol. 47 No. 4, 2019: 106 - 119

http://dx.doi.org/10.17159/2413-3221/2019/v47n4a530
Mmbengwa, Rambau,

Rakuambo, Tempia \& Qin

(License: CC BY 4.0)

Province (West Rand, Pretoria, and Germiston). Accordingly, the study used both qualitative and quantitative research approaches. These approaches were used to yield relative and comparative advantages. During the initial phase, qualitative approaches were preferred since a large amount of exploratory information was required to delineate this study. The results of the focus group sessions provided the context, understanding, themes, and constructs of the study. The latter was used to provide the variables considered in the follow-up quantitative design. This method was compatible with Participatory Action Research (PAR), which was applied at the beginning of data collection. Qualitative data were collected through focus group sessions, and quantitative data were collected through the administration of the questionnaires to the smallholder farmers. The closed-ended items of this questionnaire were validated through a peer review mechanism where experts in the agricultural industry discussed and critiqued aspects of the survey and the relevance to the research objectives. In addition, validation of the research instrument was achieved through triangulation of both qualitative and quantitative information.

\subsection{Sampling procedures}

A sample size of 78 smallholder farmers participated in the study. The eligibility to participate was based on three criteria. Firstly, respondents should be farming in one of the three regions of Gauteng. Secondly, the farm had to be functioning, in other words, producing agricultural products for the markets. Lastly, the farmers had to be linked to the Gauteng Department of Agriculture and Rural Development (GDARD) for extension support services. Non-probability sampling techniques were used in the collection of data. During sampling, a purposive sampling technique was used. According to Palys (2008), a purposive sampling technique is a technique linked to the strategic choices of the researcher's study design. In purposive sampling, selecting the sample elements is based on the researcher's judgment or expertise (Sarstedt et al, 2018). Furthermore, the researcher only includes elements he or she deems appropriate for the analysis of the effect under study. Stakeholder purposive sampling enables more data to be collected from an identified stakeholder (Saunders, Lewis \& Thornhill, 2016). The study used this sampling technique to select the appropriate stakeholders for the study as participants in the survey processes.

\subsection{Measurement of constructs}

A factor analysis was used to identify the factor loading of the latent variables (unobserved variables). A multiple linear regression model for the analysis of the composite factors of the high and low-level participations was used. These were considered as being the dependent variables in this study. Furthermore, the composite factors of variables, such as the condition of participation, institutional design, collaborative participation, and leadership were considered as being the independent variables.

\subsubsection{High-level participation}

Six items were used to measure High-Level Participation (HLP). These items included delegation, consensus, vocal, trained, access to training, and membership. The selection and measurement of this construct followed a theoretical framework, as prescribed in Ansell and Gash (2008). Furthermore, the Kaiser-Mayer-Olkin (KMO) test is a measure of how data is 
S. Afr. J. Agric. Ext.

Vol. 47 No. 4, 2019: 106 - 119

http://dx.doi.org/10.17159/2413-3221/2019/v47n4a530
Mmbengwa, Rambau,

Rakuambo, Tempia \& Qin

(License: CC BY 4.0)

suited for factor analysis, and it measures sampling adequacy and the reliability of the data in the model. The measure of sampling adequacy was also used to justify whether it was appropriate to conduct factor analysis on this construct. The results of the KMO analysis revealed that all the items were more significant than 0.6, and the overall KMO for all the items was found to be 0.771 (Table 1), implying that factor analysis for the items was warranted. Although the results of the HLP item reliability was found to be lower than a Cronbach's alpha of $0.7(\alpha=0.682)$, it was deemed to be moderately reliable. The factor loading of each factor revealed that each of the items identified in this construct was higher in all the items under consideration, implying that all items had higher contributions to the construct mentioned above.

\subsubsection{Low-level participation}

Four items were used to measure Low-Level Participation (LLP), namely being informed, meeting participation, debts, and consultation. The selection and measurement of this construct followed a similar theoretical framework as that for HLP. The KMO was also used to justify whether it was appropriate to conduct factor analysis on this construct. Table 1 indicates that the KMO of each of the items was more significant than 0.6, and the overall KMO for all the items was found to be 0.721 . These results implied that factor analysis for the items was warranted. The item reliability was conducted, and it was found that the Cronbach's alpha was greater than $0.7(\alpha=0.765)$, implying that the scale used was highly reliable. In addition, the higher factor loading revealed that each of the items identified in this construct was valuable for consideration.

\subsubsection{Condition of participation}

Six items measured the Condition of Participation (CP), namely resource, knowledge, mutual trust, membership, association, and linkages (network). The theory of participation guided the selection of these items (Ansell \& Gash, 2008). These items were measured by responses on a five-point Likert scale, where one represented 'strongly agree' and five represented 'strongly disagree'. The KMO was used to find out if a factor analysis was warranted in each item. The results (Table 1) of the KMO analysis for each item indicated that the KMO of each of the items equalled or exceeded 0.6, and the overall KMO for all the items was found to be 0.622 . These results implied that factor analysis for the items was justified. The item reliability was tested, and the results of the Cronbach's alpha was greater than $0.7(\alpha=0.732)$. This implies that the scale used was considerably reliable (i.e. there is better internal consistency of the scale). The factor loading of each factor revealed that each of the items identified in the CP had significantly higher factor loadings when analysed through principles of factor analysis (PFA).

\subsubsection{Institutional design}

The Institutional Design (ID) was measured by six items: inclusive, vision, mission, transparency, cultural beliefs, and access to experts. As with the other constructs, the selection of the items was informed by the theory of participation and intuition (Ansell \& Gash, 2008). Similarly, these items were measured by responses on a five-point Likert scale. Table 1 indicates that all the items exceeded 0.6, implying that factor analysis was justified. Furthermore, the results of the item reliability analysis showed the right internal consistency 
S. Afr. J. Agric. Ext.

Vol. 47 No. 4, 2019: 106 - 119

http://dx.doi.org/10.17159/2413-3221/2019/v47n4a530
Mmbengwa, Rambau,

Rakuambo, Tempia \& Qin

(License: CC BY 4.0)

within the items under consideration $(\alpha=0.814)$. Moreover, a higher factor loading was found, implying that each factor identified had an excellent contribution to the construct.

\subsubsection{Collaborative participation}

Six items measured the Collaborative Participation (CLP) construct which included mutual trust, mission, strategic planning, transparency, individual participation, and stakeholder participation. Similar theoretical consideration was made in selecting the factors that constitute this construct. Table 1 indicates the KMO as exceeding 0.6, implying that factor analysis for the items was warranted. In a similar vein, it was found that the item reliability was acceptable $(\alpha=0.781)$, implying that there is correct internal consistency within the items that constitute the construct. Higher factor loadings also confirm that each item plays a vital role in the building of the construct in question.

\subsubsection{Leadership}

Like other constructs, Leadership (L) was measured by five items, namely leadership roles, influence, participation, consensus, and constitution. The selection and measurements of this construct were also theoretically informed (Ansell \& Gash, 2008). The higher KMO confirmed the justification of factor analysis. The item reliability was tested, and it was found that the Cronbach's alpha was less than $0.7(\alpha=0.682)$, implying that the scale used was considered reliable. Given the higher factor loading value, each factor was deemed valuable to the composite construct.

Table 1: Reliability and factor analyses of indicators of constructs in agro-processing

\begin{tabular}{|c|c|c|c|c|c|}
\hline Items & KMO & $\begin{array}{l}\text { Factor } \\
\text { loading }\end{array}$ & $\begin{array}{l}\text { Scoring } \\
\text { coefficient }\end{array}$ & Alpha & SMC \\
\hline \multicolumn{6}{|c|}{ Indicators of conditions of participation } \\
\hline Resource participation & 0.699 & 0.624 & 0.239 & 0.717 & 0.377 \\
\hline $\begin{array}{l}\text { Knowledge } \\
\text { participation }\end{array}$ & 0.585 & 0.829 & 0.318 & 0.647 & 0.744 \\
\hline Mutual trust & 0.608 & 0.762 & 0.293 & 0.678 & 0.675 \\
\hline Membership & 0.711 & 0.505 & 0.194 & 0.723 & 0.290 \\
\hline Association & 0.578 & 0.566 & 0.217 & 0.703 & 0.503 \\
\hline Linkages & 0.652 & 0.609 & 0.234 & 0.695 & 0.404 \\
\hline Overall reliability & 0.622 & & & 0.732 & \\
\hline \multicolumn{6}{|c|}{ LR Test Chi-square $=184.29, \mathrm{P}<0.000$} \\
\hline \multicolumn{6}{|c|}{ Indicators of institutional design } \\
\hline Inclusive participation & 0.741 & 0.546 & 0.169 & 0.741 & 0.254 \\
\hline Vision & 0.701 & 0.888 & 0.275 & 0.701 & 0.848 \\
\hline Mission & 0.850 & 0.892 & 0.276 & 0.850 & 0.728 \\
\hline Transparency & 0.751 & 0.884 & 0.277 & 0.751 & 0.821 \\
\hline Cultural beliefs & 0.620 & 0.476 & 0.148 & 0.620 & 0.372 \\
\hline Access to expects & 0.712 & 0.579 & 0.180 & 0.712 & 0.381 \\
\hline Overall KMO & 0.741 & & & & 0.732 \\
\hline
\end{tabular}




\begin{tabular}{|c|c|c|c|c|c|}
\hline \multicolumn{6}{|c|}{ Indicators of collaborative participation } \\
\hline Mutual trust & 0.941 & 0.704 & 0.234 & 0.759 & 0.315 \\
\hline Mission & 0.723 & 0.839 & 0.279 & 0.724 & 0.651 \\
\hline Strategic planning & 0.824 & 0.709 & 0.236 & 0.759 & 0.371 \\
\hline Transparency & 0.688 & 0.874 & 0.290 & 0.712 & 0.718 \\
\hline Participation & 0.800 & 0.463 & 0.154 & 0.804 & 0.154 \\
\hline $\begin{array}{l}\text { Stakeholder } \\
\text { participation }\end{array}$ & 0.815 & 0.575 & 0.191 & 0.781 & 0.224 \\
\hline Overall KMO & 0.766 & & & 0.781 & \\
\hline \multicolumn{6}{|c|}{ Indicators of leadership } \\
\hline Delegation & 0.791 & 0.678 & 0.214 & 0.802 & 0.363 \\
\hline Consensus & 0.789 & 0.672 & 0.213 & 0.803 & 0.362 \\
\hline Vocal & 0.846 & 0.697 & 0.220 & 0.797 & 0.338 \\
\hline Trained & 0.824 & 0.812 & 0.257 & 0.767 & 0.493 \\
\hline Access to training & 0.789 & 0.753 & 0.311 & 0.783 & 0.399 \\
\hline Membership & 0.771 & 0.735 & 0.126 & 0.788 & 0.611 \\
\hline Overall & 0.801 & & & 0.819 & \\
\hline \multicolumn{6}{|c|}{ LR Test Chi-square $=147.85, \mathrm{P}<0.000$} \\
\hline \multicolumn{6}{|c|}{ Indicators of low-level participation } \\
\hline Informed & 0.695 & 0.844 & 0.358 & 0.649 & 0.4607 \\
\hline Meeting participation & 0.703 & 0.740 & 0.314 & 0.729 & 0.3475 \\
\hline Debts & 0.785 & 0.778 & 0.330 & 0.700 & 0.3380 \\
\hline Consulted & 0.710 & 0.699 & 0.297 & 0.751 & 0.2983 \\
\hline Overall & 0.721 & & & 0.765 & \\
\hline \multicolumn{6}{|c|}{ LR Test Chi-square $=80.24 \mathrm{P}<0.000$} \\
\hline \multicolumn{6}{|c|}{ Indicators of high-level participation } \\
\hline Leadership roles & 0.629 & 0.866 & 0.378 & 0.577 & 0.621 \\
\hline Influence & 0.592 & 0.872 & 0.381 & 0.561 & 0.626 \\
\hline Participation & 0.631 & 0.712 & 0.311 & 0.661 & 0.399 \\
\hline Consensus & 0.421 & 0.289 & 0.126 & 0.702 & 0.627 \\
\hline Constitution & 0.455 & 0.437 & 0.191 & 0.638 & 0.611 \\
\hline Overall & 0.541 & & & 0.682 & \\
\hline
\end{tabular}

Legend: $\mathrm{SMC}=$ Squared multiple correlations of variables with all other variables, $\mathrm{KMO}=$ Kaiser-Meyer-Olkin Measure of sampling adequacy, and Alpha = Cronbach's alpha.

\subsection{Analytical framework}

Hierarchical multiple linear regression models were developed to determine the factors that have an impact on the level of participation of smallholder farmers in agro-processing industries in Gauteng Province. A leadership construct was excluded in the model because the analysis found it to be insignificant at all levels of participation. The specified levels of agroprocessing smallholder participation models are set out below:

Where:

$Y_{1 \text { modelc }}=$ Low level participation (LLP), $Y_{2 \text { modelc }}=$ High level participation (HLP), $\alpha=$ constant, $\mathrm{e}=$ residual (error term), $X_{1}=$ Institutional design (ID) (CP), $X_{2}=$ Condition for participation, $X_{3}=$ Collaborative participation (CLP), $X_{4}=$ Leadership (L). 


\section{Low-level agro-processing participation model:}

The model commenced with the evaluation of institutional design as a factor that influences the lower level of participation of smallholder farmers:

$Y_{1 \text { ModelA }}=\alpha_{1}+\beta_{1} X_{1}+\mathrm{E}_{1}$

Furthermore, the model tested both institutional design and condition for participation as factors that influence lower participation of smallholder farmers in agro-processing industries of Gauteng Province:

$Y_{1 \text { ModelB }}=\alpha_{2}+\beta_{1} X_{1}+\beta_{2} X_{2}+\mathrm{E}_{2}$

Lastly, the model tested institutional design, condition for participation, and collaborative participation as factors that could influence lower participation of smallholder farmers in agroprocessing industries:

$Y_{1 \text { Modelc }}=\alpha_{3}+\beta_{1} X_{1}+\beta_{2} X_{2}+\beta_{3} \mathrm{X}_{3}+\mathrm{E}_{3}$.

\section{High-level agro-processing participation model:}

The model commenced with the evaluation of institutional design as a factor that influences the higher level of participation of smallholder farmers:

$Y_{2 \text { modelA }}=\alpha_{1}+\beta_{1} X_{1}+\mathrm{E}_{1}$

Furthermore, the model tested both institutional design and condition for participation as factors that influence higher participation of smallholder farmers in agro-processing industries of Gauteng Province:

$Y_{2 \text { modelB }}=\alpha_{2}+\beta_{1} X_{1}+\beta_{2} X_{2}+\mathrm{E}_{2}$

Lastly, the model tested institutional design, condition for participation, and collaborative participation as factors that could influence higher participation of smallholder farmers in agroprocessing industries:

$Y_{2 \text { modelc }}=\alpha_{3}+\beta_{1} X_{1}+\beta_{2} X_{2}+\beta_{3} X_{3}+\mathrm{E}_{3}$

\section{RESULTS AND DISCUSSION}

The agricultural extension (also known as agricultural advisory services) is a crucial, nonformal educational function involved in bolstering agricultural productivity, increasing food security, and improving rural livelihoods by acting as a mechanism for pro-poor economic growth (Dhehibi, Werner \& Moyo, 2018; Rivera \& Qamar, 2003). Thus, extension services enhance effectiveness in increasing productivity, profitability, and food security (Ragasa \& Mazunda, 2018). The current study sought to determine the participation of smallholder farmers in agro-processing industries, and to uncover the implications relating to participation in extension services in Gauteng Province. The results and discussion presented below seek to address the objectives by presenting both descriptive and inferential analysis results.

\subsection{Descriptive analysis of the study participants}

The descriptive analysis of the participants was presented to provide a picture of the representativeness of the sample of the study. These results were presented to show that the 
S. Afr. J. Agric. Ext.

Vol. 47 No. 4, 2019: 106 - 119

http://dx.doi.org/10.17159/2413-3221/2019/v47n4a530
Mmbengwa, Rambau,

Rakuambo, Tempia \& Qin

(License: CC BY 4.0)

researchers have removed the participants' bias and to enhance the credibility and trustworthiness of the study. According to the results, the respondents were dominated by males [53.85\% $(\mathrm{n}=42)]$, with female participants comprising the remainder of the sample size [46.15\% $(\mathrm{n}=36)]$. The average age of the respondents in this study was $53(\mathrm{SD}=14.514)$. The youngest respondents were 23 years old, while the oldest was 83 years old. Most of the participants [26 (33.3\%)] came from Emfuleni Local Municipality, followed by Ekurhuleni [21 (26.92\%) in the East Rand region and Mid-Vaal [17 (21.79 \%)] in the Sedibeng region. The study also found that smallholder farmer participation in agro-processing industries was at the highest $[39(50 \%)]$ in the category of 'other', followed by 'processed vegetables' [30 $(38.46 \%)]$.

\subsection{Inferential analysis of the factors that influence levels of participation in agro- processing}

Agricultural Extension Services (AES), defined as a system of providing advice, information, and training to farmers, is critical for enhancing agricultural productivity and development (McCormack, 2018). Ngaka and Zwane (2018) have advocated for a partnership between extension service officials and farmers to promote the participation of farmers in industries of their choices. Within the partnership context, the study explored the factors that could be associated with the participation of smallholder farmers in agro-processing industries in Gauteng Province. Inferential analysis was conducted, and the results are presented in Table 2. The results present both low and high levels of participation. This was undertaken to objectively compare the factors that could enhance the levels of participation of these farmers, with the understanding that lower participation could transform into higher participation where extension services are deemed valid.

As seen in the results, institutional design, condition of participation, and collaboration consistently appeared to be influential factors that affect the participation at all levels of participation of smallholder farmers in agro-processing industries. This observation is in agreement with participatory theories (Ansell \& Gash, 2008; Smith, 1983). Above all, Ansell and Gash (2008) highlighted that institutional design provides the basic ground rules for collaboration and participation. Macqueen et al (2014) further suggested that institutional design is instrumental in the creation of an enabling environment for participation.

However, Ansell and Gash (2008) caution that the rules that govern the participation in the institutions should be democratically and transparently formulated to curb any possible abuse or lack of support by the participants. Without transparent processes during and after the formation of the institutional arrangements or design, participation could be at risk of collapse or become unsustainable (Speelman et al, 2014). Furthermore, the institutional design should be able to deal with collective interest in relationships amongst the participants, and informal lobby networks amongst the participants (Munksgaard \& Medlin, 2014). These collective interest and lobby networks are often referred to as group dynamism in South African agricultural sectors (Mmbengwa, 2009) and have been seen to be more influential in collapsing some of the institutions and collective farming ventures in the South African smallholder farming sector.

Various authors (Ansell \& Gash, 2008; Jordaan, 2012) have confirmed the importance of these indicators for the condition of participation in enabling participants to participate. Furthermore, 
S. Afr. J. Agric. Ext.

Vol. 47 No. 4, 2019: 106 - 119

http://dx.doi.org/10.17159/2413-3221/2019/v47n4a530
Mmbengwa, Rambau,

Rakuambo, Tempia \& Qin

(License: CC BY 4.0)

this study has added to the existing body of literature on participation by providing the level of importance of these indicators in enhancing the participation of smallholder farmers in the agro-processing industries. Furthermore, it appears that in the South African smallholder farming sector, financial support, skills development and infrastructural support (i.e. resources) take priority over the knowledge of the participant, mutual trust, and linkages (Mmbengwa, 2009). Hence, there are limited regulatory frameworks that seek to provide direction regarding these latter factors.

Notably, collaboration amongst other stakeholders was found to have a reduction effect on the participation of these farmers. This seems to imply that a unit increase in collaborative activities amongst smallholder farmers and other stakeholders could disturb their growth and development. Surprisingly, leadership was found to play no role in the participation and the promotion of smallholder farmers in agro-processing industries. These results contrast with the existing theories of participation. For example, Ansell and Gash (2008) argue that the existing participation theory seems to suggest that leadership is instrumental in ensuring that the participants achieve their goals when led by leaders as facilitators. To explain the opinion of these farmers regarding this particular finding is quite challenging and complex. However, the results in question may seem to be indicative of a lack of visible leadership, and so the smallholder farmers tend to see no reason for leaders to become involved.

Moreover, these opinions of smallholder farmers may relate to political leadership, rather than the leadership from within their sector or from their members who could be elected as leaders. In this regard, it is entirely unclear whom the smallholder farmers are basing their reasons upon as to why leaders are not influencing their participation in agro-processing. The lack of agroprocessing structures may also compound the problem, to the extent that the necessity for leadership may be questionable.

Table 2: Multiple regression analysis of the factors that influence levels of participation in agro-processing by smallholder farmers in Gauteng Province

\begin{tabular}{|c|c|c|c|c|c|c|}
\hline \multirow{2}{*}{$\begin{array}{l}\text { Dependent } \\
\text { Variables } \\
\text { Variables } \\
\end{array}$} & \multicolumn{3}{|c|}{ Low participation } & \multicolumn{3}{|c|}{ High participation } \\
\hline & $\begin{array}{c}\text { Model A } \\
\beta \text { (SE) }\end{array}$ & $\begin{array}{c}\text { Model B } \\
\beta(\text { (SE) }\end{array}$ & $\begin{array}{c}\text { Model C } \\
\beta(\mathrm{SE})\end{array}$ & $\begin{array}{c}\text { Model A } \\
\text { B (SE) }\end{array}$ & $\begin{array}{c}\text { Model B } \\
\beta \text { (SE) }\end{array}$ & $\begin{array}{c}\text { Model C } \\
\beta \text { (SE) }\end{array}$ \\
\hline Inst Design & $\begin{array}{l}0.658 * * * \\
(0.086)\end{array}$ & $\begin{array}{l}0.328 * * * \\
(0.096)\end{array}$ & $\begin{array}{l}0.686 * * * \\
(0.188)\end{array}$ & $\begin{array}{l}0.601 * * * \\
(0.092)\end{array}$ & $\begin{array}{l}0.388 * * * \\
(0.114)\end{array}$ & $\begin{array}{l}0.965 * * * \\
(0.219)\end{array}$ \\
\hline $\begin{array}{l}\text { Condition } \\
\text { participation }\end{array}$ & & $\begin{array}{l}0.515^{* * *} \\
(0.096)\end{array}$ & $\begin{array}{l}0.583 * * * \\
(0.123)\end{array}$ & & $\begin{array}{l}0.332 * * * \\
(0.114)\end{array}$ & $\begin{array}{l}0.541 * * * \\
(0.143)\end{array}$ \\
\hline Collaboration & & & $\begin{array}{l}-0.524 * * * \\
(0.225)\end{array}$ & & & $\begin{array}{l}-0.792 * * * \\
(0.261)\end{array}$ \\
\hline Leadership & & & $\begin{array}{l}0.146 \\
(0.103)\end{array}$ & & & $\begin{array}{l}0.032 \\
(0.120)\end{array}$ \\
\hline Cons & 0.24 & 0.000 & 0.000 & $\begin{array}{l}0.000 \\
(0.091)\end{array}$ & $\begin{array}{l}0.000 \\
(0.089)\end{array}$ & $\begin{array}{l}0.000 \\
(0.083)\end{array}$ \\
\hline RMSE & 0.758 & 0.649 & 0.630 & 0.805 & 0.768 & 0.733 \\
\hline $\begin{array}{l}\text { Observations } \\
(\mathrm{N})\end{array}$ & 78.000 & 78.000 & 78.000 & 78.000 & 78.000 & 78.000 \\
\hline F-Statistics & 58.018 & 53.816 & 30.193 & 42.961 & 27.839 & 17.571 \\
\hline P-Value & 0.000 & 0.000 & 0.000 & 0.000 & 0.000 & 0.000 \\
\hline
\end{tabular}




\begin{tabular}{|l|l|l|l|l|l|l|}
\hline $\mathrm{R}^{2}$ & 0.433 & 0.589 & 0.623 & 0.361 & 0.426 & 0.491 \\
\hline Adj $\mathrm{R}^{2}$ & 0.426 & 0.578 & 0.603 & 0.092 & 0.114 & 0.261 \\
\hline -hat & 0.999 & 1.035 & 1.032 & 0.00 & 0.000 & 0.000 \\
\hline P-Value & 0.000 & 0.000 & 0.000 & 0.992 & 0.099 & 0.127 \\
\hline -hat sq & -0.113 & 0.103 & 0.105 & 0.805 & 0.768 & 0.733 \\
\hline P-Value & 0.426 & 0.399 & 0.358 & 78.000 & 78.000 & 78.000 \\
\hline
\end{tabular}

Legend: $* \mathrm{P}<0.05, * * \mathrm{P}<0.01,{ }^{*} * * \mathrm{P}<0.001, \beta=$ coefficient of variation, $\mathrm{SE}=$ Standard error

\section{IMPLICATIONS FOR EXTENSION SERVICES}

For the National Development Plan (NDP), participation by smallholder farmers remains one of the primary vehicles that the government could utilise to reduce poverty, create jobs, and reduce inequality (NDP, 2013). Therefore, the participation of smallholder farmers in agroprocessing has the potential to address the imperatives of the NDP, specifically in light of fostering economic development in the country. Its importance in ensuring sustainable agriculture is therefore of great significance (Botlhoko \& Oladele, 2013).

Taking into account the numerical advantages of the smallholder farmers in South Africa and their strategic positions (Aliber \& Hall, 2012), it could be deduced that including smallholder farmers into the mainstream agro-processing activities may provide some additive and comparative advantages to their farming enterprises in rural provinces. Therefore, legislative processes to ensure that smallholder farmers participate in agro-processing industries in large numbers should be put in place and be timeously monitored and evaluated. Currently, very little is known about the participation of these farmers in this sector. Institutional designs and conditions for participation must be proposed to ensure that these farmers participate in large numbers. In order to enhance participation, extension services remain an essential mentorship programme. In the context of the findings of this study, extension services could be impactful, if the influential factors of agro-processing participation are integrated into the service level agreements or policies of extension, such that the consideration of these factors is not only legislated for, but form part and parcel of the extension delivery framework.

\section{CONCLUSION AND RECOMMENDATIONS}

This study aimed to evaluate the levels of participation of smallholder farmers in the agroprocessing industries of Gauteng Province, to find out the implications of participation, or lack thereof, for the extension service. The study has successfully ascertained the factors that might positively and negatively affect the increase of participation by smallholder farmers in the agroprocessing industries in Gauteng Province. The factors that positively influence the participation were found to be the institutional design and conditions for participation. These factors provide an essential challenge for the extension services since they relate to the creation of a unique institutional framework and implementation of comprehensive support programmes. In fostering these factors, the extension service should carefully design service provision protocols that should enhance resource mobilisation, knowledge transfer, trust building, and social and human capital within the context of the existence of different cultural and governance practices in the smallholder farming sector. 
S. Afr. J. Agric. Ext.

Vol. 47 No. 4, 2019: 106 - 119

http://dx.doi.org/10.17159/2413-3221/2019/v47n4a530
Mmbengwa, Rambau,

Rakuambo, Tempia \& Qin

(License: CC BY 4.0)

\section{ACKNOWLEDGMENT}

We wish to acknowledge the Gauteng Department of Agriculture and Rural Development (GDARD) and the National Agricultural Marketing Council (NAMC) for their support.

\section{REFERENCES}

AKIDI, I.L., WAMALA, S.K. \& MUGONOLA, B., 2018. Determinants of smallholder indigenous chicken farmers, market participation decisions and value of sales in Gulu district. J. Dev. Agric. Econ., 10(8):271-278.

ALENE, A.D., MANYONG, V.M., OMANYA, G., MIGNOUNA, H.D., BOKANGA, M. \& ODHIAMBO, G., 2008. Smallholder market participation under transaction costs: Maize supply and fertilizer demand in Kenya. Food Policy, 33(4):318-328.

ALIBER, M. \& HALL, R., 2012. Support for smallholder farmers in South Africa: Challenges of scale and strategy. Dev. South. Afr., 29(4):548-562.

ANSELL, C. \& GASH, A., 2008. Collaborative governance in theory and practice. J. Public Adm. Res. Theory, 18(4):543-571.

ARNSTEIN, S.R., 1969. A ladder of citizen participation. J. Am. Inst. Plann., 35(4):216-224.

BIGGS, S.D., 1989. Resource-poor farmer participation in research: A synthesis of experiences from nine national agricultural research systems. OFCOR-Comparative Study Paper No. 3. ISNAR. Washington, D.C., United States of America.

BOTLHOKO, G.J. \& OLADELE, O.I., 2013. Factors affecting farmers' participation in agricultural projects in Ngaka Modiri Molema District, North West Province, South Africa. J. Hum. Ecol., 41(3):201-206.

DEPARTMENT OF AGRICULTURE, FORESTRY AND FISCHERIES (DAFF), 2015. Briefing note on the agro-processing in South Africa. Available from: http://pmgassets.s3-website-eu-west-1.amazonaws.com/151027brief.pdf

DHEHIBI, B., WERNER, J. \& MOYO, H.P., 2018. Developing a policy framework for agricultural extension systems in Tunisia. Available from: https://www.researchgate.net/profile/Boubaker_Dhehibi4/publication/326439211_Deve loping_a_Policy_Framework_for_Agricultural_Extension_Systems_in_Tunisia/links/5 b4d8df60f7e9b240fe50b87/Developing-a-Policy-Framework-for-Agricultural-

Extension-Systems-in-Tunisia.pdf

DOROSH, P. \& THURLOW, J., 2013. Agriculture and small towns in Africa. Agric. Econ., 44(4-5):449-459.

FAN, S., BRZESKA, J. \& HALSEMA, A., 2013. From subsistence to profit: Transforming small-scale farms. Washington, D.C: International Food Policy Research Institute.

FIGUEROA, J.L., MAHMOUD, M. \& EL-ENBABY, H., 2018. The role of agriculture and agro-processing for development in Tunisia. Washington, D.C: International Food Policy Research Institute. 
S. Afr. J. Agric. Ext.

Vol. 47 No. 4, 2019: 106 - 119

http://dx.doi.org/10.17159/2413-3221/2019/v47n4a530
Mmbengwa, Rambau,

Rakuambo, Tempia \& Qin

(License: CC BY 4.0)

HURLBERT, M. \& GUPTA, J., 2015. The split ladder of participation: A diagnostic, strategic, and evaluation tool to assess when participation is necessary. Environ. Sci. Policy, 50:100-113.

JORDAAN, H., 2012. New institutional, economic analysis of emerging irrigation farmers food value chains. PhD Thesis, University of the Free State.

LILJA, N., ASHBY, J.A. \& SPERLING, L., 2000. Assessing the impact of participatory research and gender analysis. Columbia: International Centre for Tropical Agriculture.

MACQUEEN, D., ANDAYA, E., BEGAA, S., BRINGAS, M., GREIJMANS, M., HILL, T. \& MAINDO, A., 2014. Prioritizing support for locally controlled forest enterprises. London: International Institute for Environment and Development.

MASAMHA, B., THEBE, V. \& UZOKWE, V.N., 2018. Mapping cassava food value chains in Tanzania's smallholder farming sector: The implications of intra-household gender dynamics. J. Rural Stud., 58:82-92.

MCCORMACK, C., 2018. Key factors in the use of agricultural extension services by women farmers in Babati District, Tanzania. Masters Thesis, Swedish University of Agricultural Sciences.

MIN, S., BAI, J., HUANG, J. \& WAIBEL, H., 2018. The willingness of smallholder rubber farmers to participate in ecosystem protection: Effects of household wealth and environmental awareness. Forest Policy Econ., 87:70-84.

MMBENGWA, V., 2009. Capacity building strategies for sustainable farming SMMEs in South Africa. PhD Thesis, University of the Free State.

MMBENGWA, V., KHOZA, T.M., RAMBAU, K. \& RAKUAMBO, J., 2018. Assessment of the participation of smallholder farmers in agro-processing industries of Gauteng Province. OIDA Int. J. Sust. Dev., 11(2):12-18.

MOONO, L., 2015. An analysis of factors influencing market participation among smallholder rice farmers in Western Province, Zambia. MSc Thesis, University of Nairobi.

MUNKSGAARD, K.B. \& MEDLIN, C.J., 2014. Self- and collective-interests: Using regular network activities for developing firms' business. Ind. Mark. Manag., 43(4):613-621.

NATIONAL DEVELOPMENT PLAN (NDP), 2013. The strategic plan for South African Agriculture, vision 2030. Available from: https://www.gov.za/issues/nationaldevelopment-plan-2030

NGAKA, M.J. \& ZWANE, E.M., 2018. The role of partnerships in agricultural extension service delivery: A study conducted in provincial departments of agriculture in South Africa. S. Afr. J. Agric. Ext., 46(1):14-25.

PALYS, T., 2008. Purposive sampling. In The Sage encyclopaedia of qualitative research methods (pp.697-698). New Castle: SAGE.

POPE, H.A., 2014. Participatory crop improvement: The challenges of and opportunities for institutionalization in the Indian public research sector. $\mathrm{PhD}$ Thesis, University of Sussex.

RAGASA, C. \& MAZUNDA, J., 2018. The impact of agricultural extension services in the context of a heavily subsidized input system: The case of Malawi. World Dev., 105:2547. 
S. Afr. J. Agric. Ext.

Vol. 47 No. 4, 2019: 106 - 119

http://dx.doi.org/10.17159/2413-3221/2019/v47n4a530
Mmbengwa, Rambau,

Rakuambo, Tempia \& Qin

(License: CC BY 4.0)

RIVERA, W.M. \& QAMAR, M.K., 2003. Agricultural extension, rural development, and the food security challenge. Rome: Food and Agriculture Organization of the United Nations.

ROWE, G. \& FREWER, L.J., 2000. Public participation methods: A framework for evaluation. Sci. Technol. Hum. Values, 25(1):3-29.

SARSTEDT, M., BENGART, P., SHALTONI, A.M. \& LEHMANN, S., 2018. The use of sampling methods in advertising research: A gap between theory and practice. Inter. $J$. Advert., 37(4):650-663.

SAUNDERS, M., LEWIS, P. \& THORNHILL, A., 2016. Research methods for business students. 7th ed. Harlow: Pearson Professional Limited.

SMITH, L.G., 1983. Impact assessment and sustainable resource management. Harlow: Routledge.

SPEELMAN, E.N., GARCÍA-BARRIOS, L.E., GROOT, J.C.J. \& TITTONELL, P., 2014. Gaming for smallholder participation in the design of more sustainable agricultural landscapes. Agric. Sys., 126:62-75.

THINDISA, L. \& URBAN, B., 2018. Human-social capital and market access factors influencing agro-processing participation by small-scale agripreneurs: The moderating effects of transaction costs. Acta Commercii, 18(1):1-10.

WORLD BANK, 2016. Agriculture in Africa: Telling facts from myths. Available from: http://beta.worldbank.org/en/programs/africa-myths-and-facts 
